\begin{tabular}{|l|l|l||}
\hline \multicolumn{2}{|c|}{ PublisherInfo } \\
\hline \hline PublisherName & $:$ & BioMed Central \\
\hline \hline PublisherLocation & $:$ & London \\
\hline \hline PublisherImprintName & $:$ & BioMed Central \\
\hline \hline
\end{tabular}

\title{
Agrobacteriumheat-shock proteome
}

\begin{tabular}{|l|l|l||}
\hline \multicolumn{2}{|c||}{ ArticleInfo } \\
\hline \hline ArticleID & $:$ & 4343 \\
\hline \hline ArticleDOI & $:$ & 10.1186 /gb-2002-3-6-reports0030 \\
\hline \hline ArticleCitationID & $:$ & reports0030 \\
\hline \hline ArticleSequenceNumber & $:$ & 22 \\
\hline \hline ArticleCategory & $:$ & Paper report \\
\hline ArticleFirstPage & $:$ & 1 \\
\hline \hline ArticleLastPage & $:$ & 4 \\
\hline \hline & & RegistrationDate : 2002-4-1 \\
ArticleHistory & $:$ & Received \\
& & OnlineDate 2002-4-1 \\
\hline \hline ArticleCopyright & $:$ & BioMed Central Ltd2002-5-24 \\
\hline \hline ArticleGrants & $:$ & \\
\hline \hline
\end{tabular}




\begin{tabular}{|l|l|l||}
\hline ArticleContext & $:$ & 130593366 \\
\hline
\end{tabular}

\section{Wim D'Haeze}

\section{Abstract}

A study of the proteins produced by Agrobacterium tumefaciens after heat shock gives clues to how it adapts to environmental stress

\section{Significance and context}

The bacterium Agrobacterium tumefaciens causes the serious disease of crown gall in many commercially important dicotyledonous plants. The disease is characterized by the formation of large tumor-like swellings (galls) at the crown of the plant, just above soil level. Tumors are caused by the transfer of part of $A$. tumefaciens DNA to the plant cell. Because of its horticultural importance and its use as a vector for genetic engineering in plants, $A$. tumefaciens is very well characterized genetically and biochemically, and its genome has been completely sequenced. Now, Rosen et al. have looked at how the bacterium responds to heat shock (a brief exposure to $42^{\circ} \mathrm{C}$ ), and what proteins it produces under the latter conditions. In bacteria, transcription of genes encoding heat-shock proteins is most commonly controlled by the CIRCE (controlling inverted repeat of chaperone expression)-HrcA regulatory system and by the RpoH system, which encodes a $\sigma^{32}$ sigma factor (a gene-regulatory transcription factor). Rosen et al. have found a complex response to heat shock in A. tumefaciens, including a large number of proteins whose production is independent of the action of $\mathrm{RhoH}$.

\section{Key results}

The sets of proteins produced by $A$. tumefaciens under standard conditions and after heat shock were compared using two-dimensional gel electrophoresis. In the latter case, 56 heat-shock-specific proteins were identified, which could be subdivided into three groups: RpoH-dependent proteins ( 24 proteins); the chaperones GroEL and GroES, production of which is repressed by HrcA under non-heat-shock conditions; and 32 proteins whose production depends on hitherto unknown regulatory mechanisms, as they were produced by an rpoH mutant under heat-shock conditions. An example of a protein produced independently of both $\mathrm{RpoH}$ and $\mathrm{HrcA}$ is protein $\mathrm{H} 35$, a high-affinity phosphate-transport protein involved in the phosphate influx that occurs during heat shock. A comparison of the heat-shock proteins produced by an $r p o H$ - $h r c A$ double mutant with those produced by a wild-type strain suggested a pleiotropic effect, which was not observed when both single mutants were considered separately, and still needs to be deciphered. Heat-shock proteins sequenced and identified include $\sigma^{32}$-dependent and 
$\sigma^{32}$-independent forms of SmoM, a periplasmic mannitol-binding protein; H26-G, a general stress protein that functions as an L-threonine aldolase, responsible for the conversion of serine into glycine; PstB, a hypothetical transcriptional regulator; a ribosomal protein, L7/L12; and a ketol acid reductoisomerase.

\section{Links}

The entire genome sequence of $A$. tumefaciens $\mathrm{C} 58$ is presented at the Agrobacterium tumefaciens C58 Cereon genome page, and more detailed information about plant diseases mediated by $A$. tumefaciens is available at The Microbial World: biology and control of crown gall.

\section{Conclusions}

Analysis of heat-shock-induced proteins in Agrobacteriumwill strengthen our understanding of how the $\beta$-proteobacteria, the group to which Agrobacterium belongs, adapt to stress-inducing conditions. It may also be useful in understanding the very closely related Brucella species, the cause of brucellosis in humans and other animals.

\section{Reporter's comments}

The work by Rosen et al. describes a partial characterization of heat-shock proteins produced by the plant pathogen $A$. tumefaciens. Future work should, for instance, include the determination of the relevance of the heat-shock proteins studied here for the induction of particular plant diseases and whether abolition of their production also blocks the induction of the disease. It would furthermore be interesting to search for similar heat-shock or other stress-induced proteins in, for instance, Brucella sp., and unravel the importance of these proteins for infection of humans.

\section{Table of links}

Journal of Bacteriology

Agrobacterium tumefaciens C58 Cereon

The Microbial World: biology and control of crown gall 


\section{References}

1. Rosen R, Büttner K, Becher D, Nakahigashi K, Yura T, Hecker M, Ron EZ: Heat shock proteome of Agrobacterium tumefaciens: evidencefor new control systems. J Bacteriol. 2002, 184: 1772-1778. 0021-9193

This PDF file was created after publication. 